\title{
EMPLOYMENT AND VALUE-ADDED CONTRIBUTION OF SLOVENIAN HIGH-GROWTH COMPANIES (GAZELLES)
}

\author{
Katja Crnogaj*, Karin Širec \\ Faculty of Economics and Business, University of Maribor, Maribor, Slovenia
}

High-growth companies, gazelles, are responsible for stimulating economic growth and development through extreme growth rates (employment, income, assets, value-added etc.). Consequently, exploring highgrowth companies may offer valuable insights into promoting dynamic entrepreneurship in contemporary society. In this paper, we are examining high-growth companies and their socio-economic contribution through a company's size, because the size dimension is an important characteristic affecting the level of employment and making important contributions to employment growth. Based on the national ranking of the 500 fastest-growing companies, based on the income statement data (sales growth in the 5-year period), we compare the gazelles with the average of all Slovenian companies. The findings provide evidence of the gazelles' considerable contribution to employment and the creation of an added (new) value. Company growth can also be measured on the basis of other parameters and therefore, in one part of our analysis, we limit the use of the measures to the relative employment growth - the DaBeg index. The results have shown that the growth patterns among the companies are very heterogeneous and that innovative fast-growing companies make a valuable socio-economic contribution. As such, gazelles require effective supportive measures of government policies, aimed at encouraging and promoting growth-oriented entrepreneurship.

Keywords: high-growth companies (gazelles), DaBeg index, small and medium-sized companies, employment growth, value added

JEL Classification: L25, L26

\section{INTRODUCTION}

Researchers, economic policy makers and other experts all agree that company growth is in itself a good indicator of business success. However, different studies have shown that growth intentions and the sources of growth are not evenly distributed among

\footnotetext{
* Correspondence to: K. Crnogaj, Faculty of Economics and Business, University of Maribor, Razlagova 14, 2000 Maribor, Slovenia; e-mail: katja.crnogaj@uni-mb.si
}

entrepreneurially oriented companies. In this paper, we therefore try to find an answer to the question: Why do some firms continue to create new employment and find innovative solutions to old problems (i.e. they are growing) whereas others-the majority of them-remain small and behave in accordance with the traditions of their respective industry? The Global Entrepreneurship Monitor (GEM) has been studying entrepreneurial aspirations for growth from the perspective of the expected number of new vacancies 
for years, and their research has shown that highgrowth entrepreneurs represent only $4 \%$ of the total entrepreneurs, yet the business they have founded or co-owned created close to $40 \%$ of the total jobs generated by all entrepreneurs (Morris, 2011). Other research results also confirm that the entrepreneur's decision on how much he/she wants to expand their business plays an important role in the development of the company; they show that entrepreneurial growth aspirations actually lead to a quick growth of the company (Baum, Locke \& Smith, 2001; Wicklund \& Shepherd, 2003).

Although some surveys have demonstrated that growth is not an objective for all small and mediumsized firms, the ability of firms to grow is important as it has been suggested that firms with low or negative growth rates are more likely to fail (Phillips \& Kirchoff, 1989). The results of the first analysis of 5,000 dynamic small firms in Slovenia have shown intensive growth in employment rates: these firms opened as many as 22,514 new vacancies in the 5 -year period between 2003 and the end of 2007, which accounts for $60 \%$ of all new vacancies in the time studied. Value added per employee increased by almost $70 \%$, the net value added increased almost three times, and the sales revenues increased more than 2.5 times (Pšeničny, 2008). The European Commission is also aware of the importance of company growth; it revised the Lisbon Strategy in 2005, emphasizing the key measures for creating growth and new jobs in the European Union. The Small Business Act includes an indicator which measures the share of fast-growing companies depending on employee growth (European Commission, 2010). The data is based on the Eurostat indicators. The share of fast-growing companies for 2009 was only available for 16 European countries (Bulgaria, Italy, Austria, The Czech Republic, Hungary, Sweden, Spain, Luxemburg, Great Britain, Finland, the Netherlands, Denmark, Germany, Belgium, France and Romania). According to their estimate, Bulgaria has the biggest number of fast-growing companies (8.83\%), and is followed by Italy (8.07\%) and Austria (6.90\%). The Czech Republic (with 5.37\%), Hungary (4.99\%) and Sweden (4.58\%) are also above the European average. This leads to the conclusion that the more developed members of the EU have smaller shares of fast-growing companies in relation to employee growth. For other European countries, such as Slovenia and Serbia, there is no comparable data. However, the fact that the average number of fast-growing companies in relation to employee growth in the USA $(7.13 \%)$ is far from the European average $(4.31 \%)$ is a sufficient indication. The findings of the European Commission thus confirm the importance of gazelles and justify the relevance of research in this field.

The intention of our research is to estimate the socioeconomic contribution of gazelles on the basis of the national rankings of the 500 fastest-growing companies in 2009 (the rise in sales revenue in a five-year period), and on the basis of the DaBeg index from 2004 to 2008 $(\mathrm{N}=500)$, through employment and creating value added. The sample is a good basis for the analysis of fastest-growing companies which, through generating jobs and creating an added (new) value, stimulate economic growth and development in Slovenia and other European countries.

For creating economic growth/development and value added, it is important that the state, with its measures, should stimulate and support company growth. The promoting of entrepreneurial activities is primarily in the domain of the state which has to shape and implement the economic policy with a positive impact on creating and developing new and growing companies. In order for the state to be able to create conditions for company growth, it must first understand how companies grow and what the background of this growth is.

\section{LITERATURE REVIEW AND RESEARCH HYPOTHESES}

Small firm growth is neither a self-evident phenomenon nor a matter of chance. According to the literature, various factors affect firm growth. In line with the Penrosean theory of growth (Penrose, 1959), it is widely agreed that growth occurs whenin addition to motivation and opportunity-proper strategy and corresponding resources are also in place (Gilbert, McDugall \& Audretsch, 2006). G. Cassar (2007) showed that an entrepreneur's growth 
aspirations are influenced by opportunity costs related to the use of human and financial capital. Some recent studies (Autio \& Acs, 2009) have also suggested that the deployment of human and financial capital is influenced by national conditions regulating the appropriateness of expected returns from capital deployment.

Approximately a quarter of a century ago, D. L. Birch coined the term gazelles to refer to a small group of high-growth companies (Landström, 2005, 170) that generated a disproportionately large share of new jobs in the economy (Birch, 1979; 1981; 1987). According to him, gazelles are dynamic companies which grow fast, develop very rapidly, employ workers intensively and are always one step ahead of their competition. Their goal is not to survive, but to succeed. Most of them are small firms working selflessly and carefully choosing the first collaborators before they start their rapid growth. When this happens, it is important to acquire capital for rapid growth and equally quickly find adequate people for new tasks within the company. In spite of their importance, there is surprisingly little evidence in support of D. L. Birch's claim. According to M. Henrekson and D. Johansson (2010), only 20 relevant studies have been published since 1990. The reasons for such a limited research might be the lack of suitable data, the cost of carrying out such studies and a relatively recent interest in these issues.

The fact is that the patterns of company growth are very heterogeneous and that there are numerous different measures and methods used for understanding this process. Firm growth can be measured by several attributes, such as turnover/ sales, employment, assets, market shares, and profits (Zhou \& de Witt, 2009). Surprisingly, and despite its economic upside potential, growth research has predominantly focused on ",normal"-to-,,high" growth rates $(5 \%$ to $20 \%$ ), while overlooking formidably high-growth or "hyper-growth" rates (measured by hundreds to thousands of percentages-in our case, a firm's five-year sales growth rate ranges from $382 \%$ to 10,240\%). A similar approach was previously adopted by, for example, S. Roper (1999) and M. Niskanen and J. Niskanen (2007). Although most research in this field examines growth through employment rates, another important company growth indicator is the Birch index - DaBeg (Birch, 1987), which can refer to changes in the number of employees, value added or the combination of the two factors. In our research, the DaBeg index denotes employee growth in a given period and takes into account the absolute and the relative employment growth (Birch, 1987, 36-37), which enables the comparison of micro, small, medium and large companies:

$$
\text { DaBeg }=\left(Z_{t n}-Z_{t n-5}\right) \times \frac{Z_{t n}}{Z_{t n-5}}
$$

$\mathrm{Z}=$ the absolute number of employees in a given year (tn).

The DaBeg index is also a highly selective criterion of Europe's 500 rank list (2011a), which annually announces the list of the 500 fastest-growing companies in Europe. The 500 companies on Europe's 500 rank list in 2007 (2011b) had employed 297,455 new workers between 2003 and 2006, which amounts to a total of 598,796 employees in those companies (data for December 2006). The total of 297,455 new vacancies accounts for an increase of almost 100,000 vacancies a year, i.e. 198 new vacancies per company a year. However, the rank list only includes one Slovenian company that opened 486 vacancies in a period of three years, which is 162 new vacancies a year (Figure 1).

Given their vacancy-creating potential, fast-growing companies attract the attention of economic policy makers, whose wish it is to reduce unemployment rates and encourage economic growth and development. J. Roure $(1999,53)$ claims that small and medium firms, especially their fastest-growing parts, created more jobs in Europe in the last five years of the previous millennium than there were lost jobs by the largest companies, achieving records in their revenue and profit growth along the way. R. D. Ireland, M. A. Hi and D. G. Simon (2003, in: Steffens, Davidsson \& Fitzsimmons, 2009, 126) claim that smaller firms are on average more efficient in recognizing new business opportunities, which enables them further growth and reflects itself on the studied population as a larger average number of employees in micro-, small and 


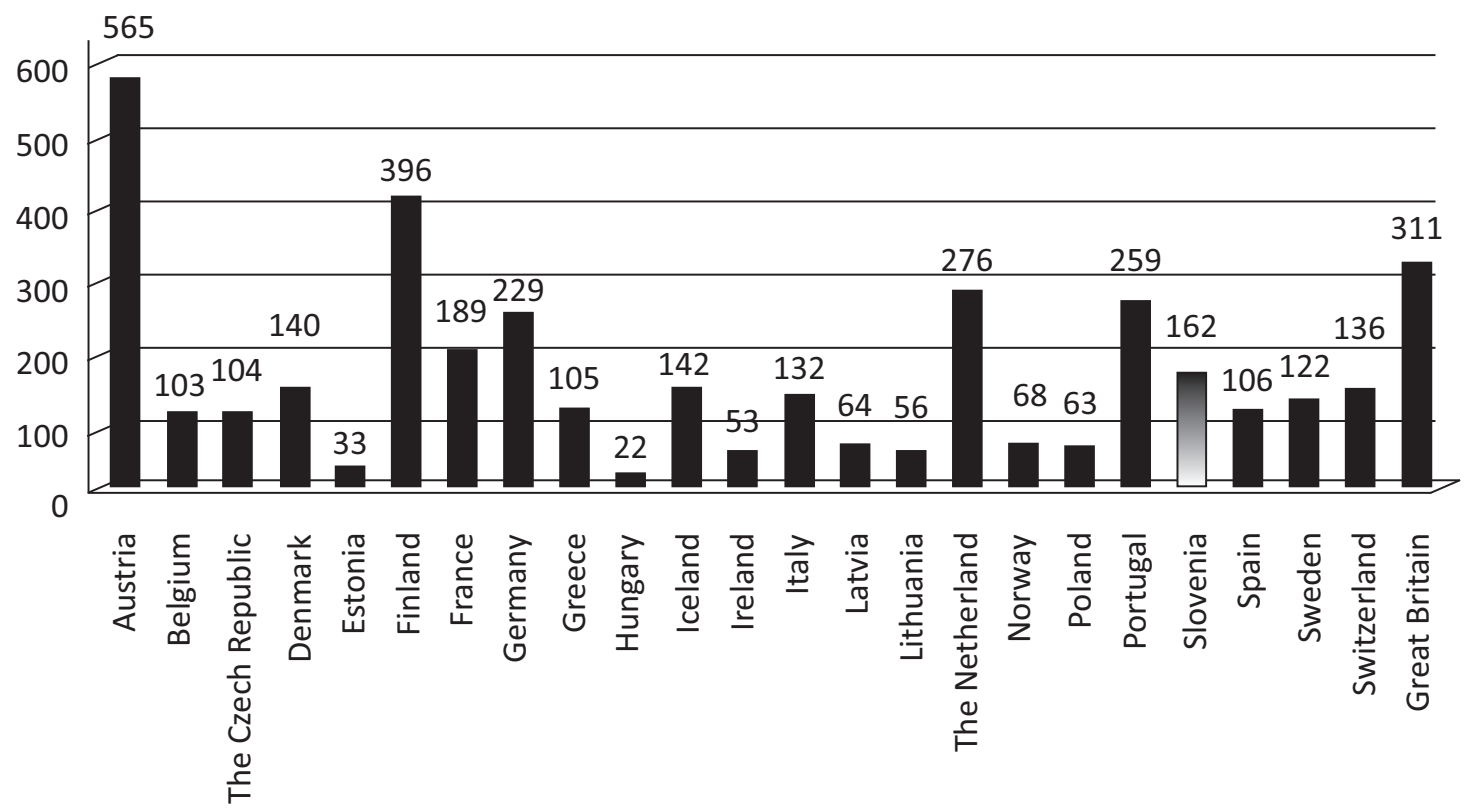

Figure 1 Absolute annual employment growth

Source: Authors, adapted from Europe's 500, 2011b

medium . On the basis of this, we shall test hypothesis H1:

$\mathrm{H} 1$ : Small and medium fast-growing companies have more employees per company compared to the average of all small and medium Slovenian companies.

In the literature on economics, different theories and research into company size and its connection with growth have developed around the analysis of the company size distribution. The most well-known is R. Gibrat's law (1931), according to which growth rates are not linked to the company size. This law has prompted a lot of other research, some of which have shown that growth rates indeed do not depend on the company size while others have claimed that the law only applied to large companies, rather than to the small ones, whereas some have claimed that growth rates decrease with an increase in the company size (Evans, 1987; Storey, 1995; Dunne \& Hughes, 1996; Sutton, 1997; Wagner, 1992; in: Delmar, Davidsson, \& Gartner, 2003, 196). In that sense, growth patterns are very heterogeneous when it comes to companies and results considerably depend on the chosen research methodology and how growth is measured.

However, it is important to note that, generally speaking, bigger companies have more funds to further develop their competitive advantages and thus more opportunity for a successful implementation of a fast growth strategy (Steffens et al, 2009). Since in our case we only limit ourselves to fast-growing companies and to using the DaBeg index showing employee growth in a given period, hypothesis $\mathrm{H} 2$ is as follows:

$\mathrm{H} 2$ : The size of a Slovenian fast-growing company has an impact on its higher employment growth rate.

It is not only essential for an entrepreneurial activity to be making a profit but also to be creating an added (new) value. Small companies are generally thought to hardly ever contribute to an increase in wealth in a society and mainly large companies are generally thought to create the highest value added per employee. However, since gazelles are well-known as the driving 
force of economic development, value added per employee is expected to be higher in gazelles than the average value added per employee in other companies. Therefore we shall also examine hypothesis H3:

H3 : Fast-growing companies report higher value added per employee compared to the average of all Slovenian companies.

\section{RESEARCH METHODOLOGY}

The empirical study was performed on Slovenia's fastest-growing companies. The dataset of high-growth companies from around the nation was provided by the newspaper company Dnernik and primarily collected by Bisnode Ltd Company. More precisely, the newspaper Dneonik publishes the list of the 500 fastestgrowing companies in Slovenia, where firms are ranked by their sales growth over a 5 -year period in all the Standard Industry Classification (SIC) categories. The selected companies must match the following criteria: generating a profit in the income statement of the last observed year, with at least 220,500 euro in revenues from sales in the base year; operating all 12 months in both index years; and reporting a profit in the last year. The pattern thus enables a five-year longitudinal perspective of fast-growing companies from the whole country.

The statistical population of this research (gazelles in Slovenia) is comprised according to the list of the 500 fastest-growing companies in 2009 (the sales growth index from 2004 to 2008; the DaBeg index from 2004 to 2008; $N=500$ ). In the research, we used the quantitative research methods. Beside descriptive statistics, the chi-square test for testing the independence of two variables was also used. The general criterion for accepting the hypotheses is based on the statistically significant difference of 5 per cent (two-way test).

\section{EMPIRICAL RESULTS}

The total of 500 Slovenian fastest-growing companies in 2009 opened 8,682 new vacancies in the period between 2004 and 2008; in 2004, a gazelle employed
14 workers on average, and by 2008, the average number of employees rose to 32 . In five years, the sales increased seven times on average (Table 1).

Table 1 Survey of Slovenian fast-growing companies gazelles

\begin{tabular}{|c|c|c|}
\hline INDICATORS & $\begin{array}{l}\text { Year } 2009 \\
(2004-2008)\end{array}$ & $\begin{array}{l}\text { Year } 2003 \\
(1998-2002)\end{array}$ \\
\hline \multicolumn{3}{|l|}{ SALES } \\
\hline Average sales (s. year) ${ }^{1}$ & $1,222,680 €$ & $405,889 €$ \\
\hline Total sales (s. year) & $611,340,066 €$ & $202,944,563 €$ \\
\hline Average sales (f. year) ${ }^{2}$ & $8,376,971 €$ & $1,495,811 €$ \\
\hline Total sales (f. year) & $4,188,485,776 €$ & $747,905,718 €$ \\
\hline $\begin{array}{l}\text { Sales index } \\
\text { (f. year / s. year) }{ }^{3}\end{array}$ & 685.1 & 368.5 \\
\hline \multicolumn{3}{|l|}{ VALUE ADDED } \\
\hline $\begin{array}{l}\text { Average value added } \\
\text { (s. year) }\end{array}$ & $280,382 €$ & $99,667 €$ \\
\hline $\begin{array}{l}\text { Total value added } \\
\text { (s. year) }\end{array}$ & $140,190,895 €$ & $49,833,356 €$ \\
\hline $\begin{array}{l}\text { Average value added } \\
\text { (f. year) }\end{array}$ & $1,361,945 €$ & $304,818 €$ \\
\hline $\begin{array}{l}\text { Total value added } \\
\text { (f. year) }\end{array}$ & $680,972,566 €$ & $152,408,913 €$ \\
\hline $\begin{array}{l}\text { Value added index } \\
\text { (f. year/s. year) }\end{array}$ & 485.8 & 305.8 \\
\hline \multicolumn{3}{|l|}{ EMPLOYEES } \\
\hline $\begin{array}{l}\text { Average number of } \\
\text { employees (s. year) }\end{array}$ & 14 & 24 \\
\hline $\begin{array}{l}\text { Total number of } \\
\text { employees (s. year) }\end{array}$ & 7,108 & 12,133 \\
\hline $\begin{array}{l}\text { Average number of } \\
\text { employees (f. year) }\end{array}$ & 32 & 40 \\
\hline $\begin{array}{l}\text { Total number of } \\
\text { employees (f. year) }\end{array}$ & 15,790 & 20,073 \\
\hline $\begin{array}{l}\text { Number of employees } \\
\text { index (f. year / s. year) }\end{array}$ & 222.1 & 165.4 \\
\hline New vacancies & 8,682 & 7,940 \\
\hline $\begin{array}{l}\text { Average DaBeg index } \\
\text { (f. year / s. year) }\end{array}$ & 120.2 & $\begin{array}{l}\text { No data } \\
\text { available }\end{array}$ \\
\hline
\end{tabular}

Source: Authors, adapted from Basle, 2003, in: Boštjančič, 2005; Solina, 2011 
The data collected for the period of five years from 2004 to 2008 provide us with an overall picture of the Slovenian fast-growing companies in 2009. For the sake of comparison, the comparable data on gazelles in 2003 were added.

The average DaBeg Birch index for the Slovenian gazelles in 2009 shows the value of 120.2, which in itself, without comparison, does not tell us much. Therefore, we shall stress the fact that the total number of employees from 2004 to 2008 grew by 8,682 persons, which amounts to the total of 15,790 employees. The comparison with the gazelles in 2003 comes as a surprise (the 2002 - 1998 growth index) because the number of the employees in the final year of 2002 is bigger, and that was the period when the Slovenian gazelles employed the total of 20,073 persons. Such a difference in the number of employees can be explained by the global financial crisis which started destroying global financial markets at the end of 2008 and turned into the so-called social crisis a year later, which primarily reflected in massive layoffs. From the results, we have concluded that the consequences of the global financial crisis reflect on the Slovenian fastgrowing companies as well.

Prior to our starting analyzing the relation between the company size and various growth patterns, it is important that the structure of the Slovenian fastgrowing companies should be defined in comparison to the size of all the companies in Slovenia in general (Table 2).

Table 2 Comparison between the fast-growing and all other companies in Slovenia

\begin{tabular}{l|cc}
\hline SIZE GROUPS & $\begin{array}{c}\text { Companies } \\
\text { in 2008 }\end{array}$ & Gazelles \\
\hline Micro companies (0-9) & $93.6 \%$ & $67.3 \%$ \\
Small companies (10-49) & $5.1 \%$ & $22.4 \%$ \\
Medium-sized companies (50-249) & $1.1 \%$ & $6.1 \%$ \\
Large companies (250 and more) & $0.2 \%$ & $4.2 \%$ \\
\hline TOTAL & $100 \%$ & $100 \%$ \\
\hline
\end{tabular}

Source: Močnik, 2010 and Authors' calculations
The comparison reveals a considerably lower percentage of micro-firms among the gazelles and a higher percentage in the group of the fast-growing companies, which should be taken into consideration when interpreting the further analysis results.

\section{Fast-growing companies and the number of employees}

Given the fact that the company size is an important factor impacting the employment rate and contributing to employment growth, our research examines employment in fast-growing companies in particular size groups and compares them to the general company size in Slovenia. The empirical researches done so far have shown that - in economy - there is usually a small group of companies (gazelles) accountable for a substantial number of all the generated jobs. That brings us to the conclusion that the Slovenian companies included in the list of the 500 fastest-growing companies in 2009 employed a total of 15,790 persons in the final index year of 2008, and according to the Slovenian Entrepreneurship Observatory data (Močnik, 2010, 19) there were 119,207 companies employing the total of 620,053 persons in 2008. Consequently, an average company employed approximately 5.2 persons, whereas an average gazelle employed as many as 32 persons (Figure 2 and Table 1).

Employment in the fast-growing companies in the particular size groups in comparison to the general company size in Slovenia shows that in all the size groups, except with large companies, the average number of employees per company is bigger among the Slovenian gazelles. The biggest discrepancy is visible among the micro-firm groups, where the gazelles employ almost five (4.9) persons, and at the level of all the companies - the number is somewhat lower than two (1.8). All the micro-gazelles, small and medium gazelles (SME) also show a bigger average number of employees per company. The gazelles in the SME group usually employ 27.2 employees per company and all the Slovenian companies in the SME group employ almost 8 times fewer (3.5). However, a reverse ratio is noticeable in the large companies; yet, when all the Slovenian gazelles are compared with all the companies in Slovenia, the ratio is still very much in favor of the 


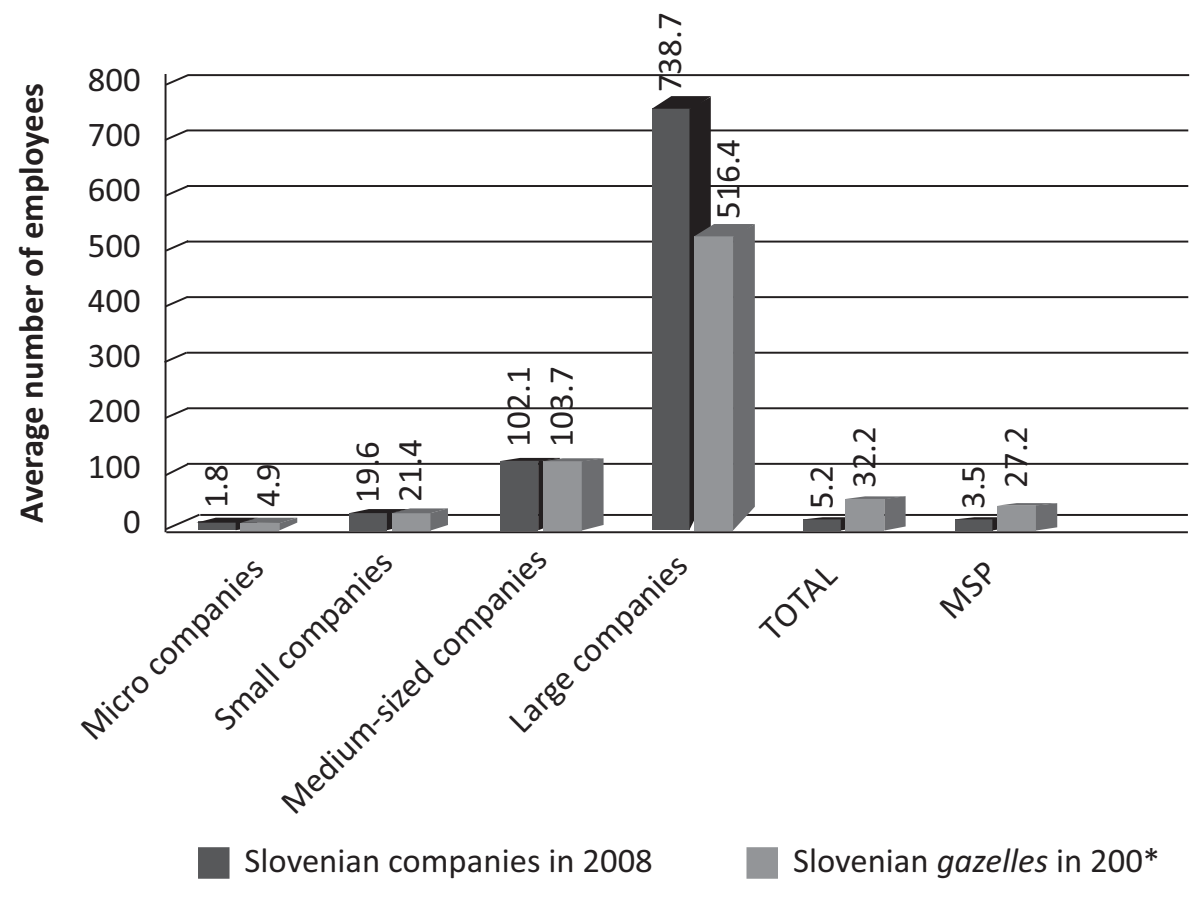

*Slovenian gazelles (2004-2008)

Figure 2 The average number of employees per company in particular size groups

Source: Močnik, 2010 and Authors' calculations

first ones. The Slovenian gazelles employ approximately six times more people (32.2 as compared to 5.2) on average.

The results show that, on average, the Slovenian gazelles employed more than all the other Slovenian companies, and that the average number of employees in comparison to all the companies is primarily bigger in smaller gazelles (SME). Therefore we can conclude that small and medium fast-growing companies reflect a bigger number of employees per company compared to the average of all Slovenian SMEs. For that reason, we accept hypothesis $\mathrm{H} 1$ in full.

The reasons for the bigger average number of employees in Slovenian large companies should be linked to their long tradition. In most cases, these are large business systems which very slowly adapt to structural changes and do not depend so much on the market conditions as it is the case with large companies in the gazelles group.

\section{The employment growth rates of fast-growing companies}

A comparative analysis of the size of gazelles and employment growth in them is demonstrated in Table 3. In order to determine employment growth, we used the DaBeg indicator and divided it into four logical categories (moderate growth, rapid growth, superrapid growth and hyper-growth). The companies with the "hyper-growth" of employment account for the top $12.5 \%$ of the companies with impressive growth, employment in the bottom-ranking $41 \%$ of the companies grows at approximately the same „moderate" growth rate; the two middle groups are 
Table 3 The comparative analysis of the size of gazelles and employment growth in them (DaBeg) ${ }^{4}$

\begin{tabular}{|c|c|c|c|c|c|c|c|}
\hline & & & \multicolumn{4}{|c|}{ Growth rates } & \multirow[b]{2}{*}{ TOTAL } \\
\hline & & & $\begin{array}{c}\text { Moderate } \\
\text { growth }\end{array}$ & $\begin{array}{l}\text { Rapid } \\
\text { growth }\end{array}$ & $\begin{array}{l}\text { Super } \\
\text { rapid } \\
\text { growth }\end{array}$ & $\begin{array}{l}\text { Hyper } \\
\text { growth }\end{array}$ & \\
\hline \multirow{6}{*}{$\begin{array}{l}\text { Size } \\
\text { groups }\end{array}$} & \multirow{2}{*}{ Micro gazelles } & Count & 105 & 15 & 4 & 0 & 124 \\
\hline & & Expected Count & 50.8 & 31.7 & 26.0 & 15.5 & 124.0 \\
\hline & \multirow{2}{*}{ Small gazelles } & Count & 65 & 81 & 63 & 12 & 221 \\
\hline & & Expected Count & 90.5 & 56.4 & 46.3 & 27.7 & 221.0 \\
\hline & \multirow{2}{*}{ Medium gazelles } & Count & 0 & 10 & 20 & 36 & 66 \\
\hline & & Expected Count & 27.0 & 16.9 & 13.8 & 8.3 & 66.0 \\
\hline & \multirow{2}{*}{ TOTAL } & Count & 170 & 106 & 87 & 52 & 415 \\
\hline & & Expected Count & 170.0 & 106.0 & 87.0 & 52.0 & 415.0 \\
\hline
\end{tabular}

Source: Authors

divided with regard to the approximately equal share of the remaining companies.

We have found that the speed of employment among various company size groups statistically differs (X2(9) $=287.014, p=0.000 ; \varphi=$ Cramer's V = 0.480). By further examining, we managed to confirm the fact that the bigger a dynamic company is, the bigger employment growth it has. A more detailed analysis has shown that micro gazelles and small gazelles display lower growth rates, whereas medium gazelles and especially large gazelles demonstrate the markedly higher rates of super-fast and hyper-fast growth than expected. Therefore, we can confirm hypothesis H2, according to which the size of a Slovenian fast-growing company has an impact on its higher employment growth rate.

In spite of the claims made by F. Delmar et al. (2003) (that although the company size has an impact on growth, it is still unclear in what way), limiting ourselves to employment growth according to the DaBeg index, we have found out that the bigger a dynamic company is, the bigger its growth rate is. On the basis of this, we can conclude that a company must, first, attain a certain size if it wants to implement fast growth strategies. Namely, bigger companies have more funds to further develop their competitive advantages and more opportunities to successfully implement a fast growth strategy, as the research done by R. D. Ireland et al. (2003) confirmed.

\section{The value added of fast-growing companies}

Compared to the current prices, the Slovenian economy made 21.1 billion euro of value added during 2008 . The average value added per employee (an indicator of labor productivity) in Slovenian companies in 2008 was 34,006 euro. Large companies' productivity was above-average because their average labor productivity was 38,334 euro (or 13\% above the average). SMEs, with 31,919 euro per person, are averagely productive (lagging $6 \%$ behind the average). The most productive among the SMEs are small companies with the above average of 36,113 euro. The least productive are microfirms (with 1 to 9 employees), with 25,230 euro per employee (including the self-employed persons) D. Močnik (2010, 25). Table 1 shows the value added per employee; since the beginning of the transition period, Slovenia has been documenting lower rates compared to the ones achieved by companies in other innovative economies. It is stimulating that the Slovenian gazelles achieved the average value added of 1,361,945 euro on average, which is almost 5 times more compared to 2004 (280,382 euro).

Figure 3 shows the comparison of the value added per employee in the Slovenian gazelles ranked on the list 


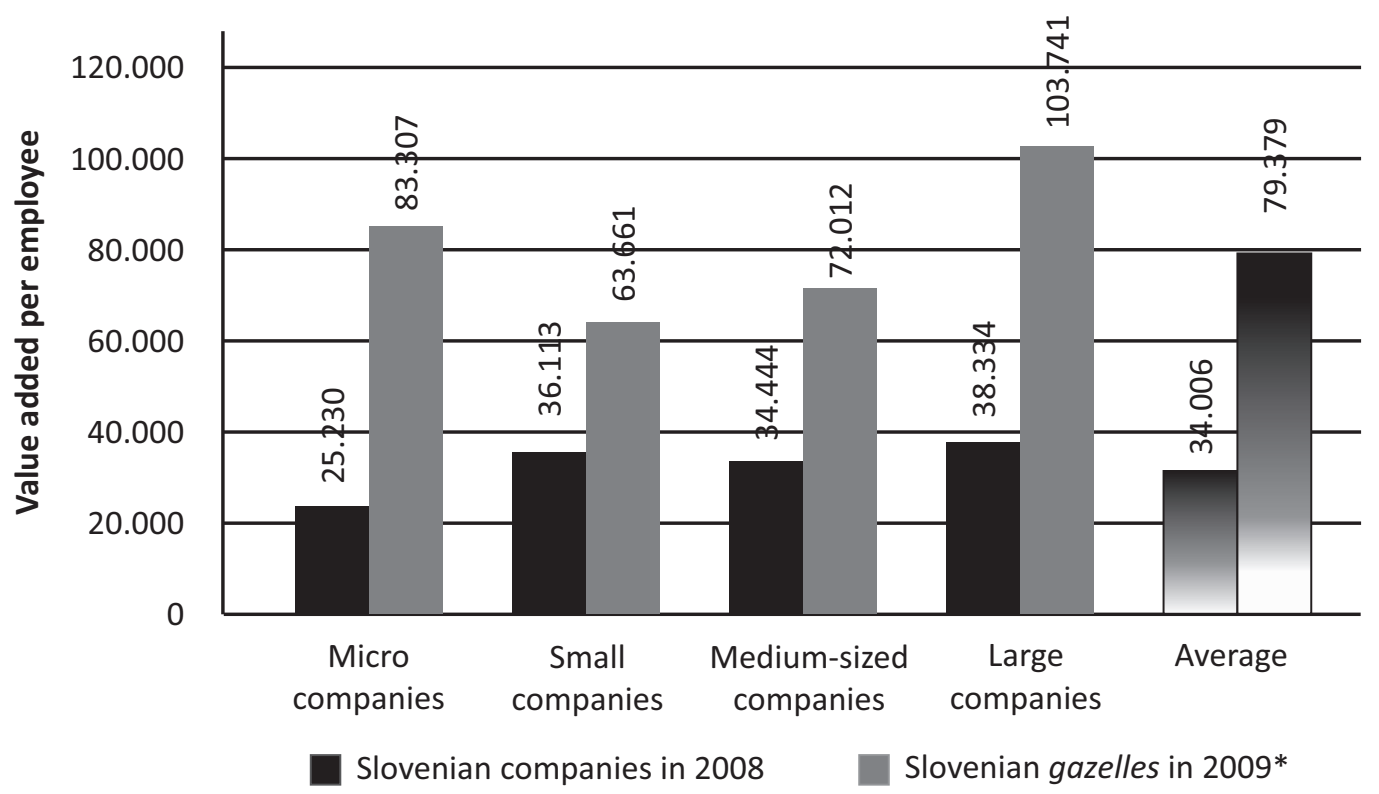

*Slovenian gazelles 2009 (2004-2008)

Figure 3 Value added per employee in particular size groups

Source: Močnik, 2010 and Authors' calculations

of the 500 fastest-growing companies in 2009 with the value added per employee in Slovenian companies according to the size groups in 2008. The results of the comparison show that the average value added per employee in the Slovenian gazelles is 2.3 times higher than the average value added per employee in all Slovenian companies. It is interesting that the biggest difference is noted by exactly the companies from the group of the micro-firms whose average value added per employee is as much as 3.3 times higher than the average Slovenian micro-firm. The large gazelles, with the average value added per employee higher by 2.7 times, only rank the second.

On the basis of this, we can confirm hypothesis $\mathrm{H} 3$, according to which the fast-growing Slovenian companies report a higher value added per employee compared to the average of all Slovenian companies. Given the fact that the average European value added per employee in 2008 was half as high as the Slovenian one (Močnik, 2010), innovative and fast-growing companies constituting a great potential for the growth of the economy and the creation of a value added are even more important. We can partly substantiate our claims using the assertion made by J. Bos and E. Stam (2011, 11), who state that gazelles are relatively capitalintensive enterprises and thus employ fewer persons in order to achieve an equal amount of the value added; in other words, their value added per employee is all that much higher.

\section{CONCLUSIONS}

The two recent studies of entrepreneurship - Global Entrepreneurship Monitor (Rebernik, Tominc, Crnogaj, Širec \& Bradač Hojnik, 2013) and Slovenian Entrepreneurship Observatory (Rebernik, Širec \& Močnik, 2014) - have shown that the entrepreneurial potential in Slovenia is not fully utilized. The reasons for this can be sought in resource scarcity, 
environmental uncertainty and the weak institutional support. To create economic growth and a high value added, it is important that first and foremost company growth should be stimulated. Growth is the result of the owner's / entrepreneur's motivation, which is driven by their conviction that the desired results can be achieved. It is on this basis that we have found the answer to the question: Why do some firms continue to create new employment and find innovative solutions to old problems (i.e. they are growing) whereas othersthe majority-remain small and behave in accordance with the traditions of their respective industry?

Thus, growth is assumed to be beneficial and something that entrepreneurial firms should attempt to achieve (Sexton \& Smilor, 1997, in: Markman \& Gartner, 2002, 66). E. T. Penrose (1959) argued that growth-oriented firms may be more likely to attract extraordinary management talent as well as financial support from investors, allies, and competitors. An increase in the number of companies relates to the quantitative aspects of economic growth while small business growth relates to the qualitative aspects of economic growth or with the so-called economic development.

The analysis of the gazelles $(\mathrm{N}=500)$ has shown that the growth patterns among companies are very heterogeneous and that exploring them by applying various methods is very significant for a future deeper understanding of company growth. For the needs of the research, the rank list of the 500 fastest-growing companies in Slovenia was referred to; this list was created on the basis of the income statement data (sales revenue growth in a five-year period). Since company growth can be measured on the basis of some other parameters, in one part of this analysis of ours, we confined to using the relative employment growth criterion - the DaBeg index. The comparison of the average number of employees per company has shown that the Slovenian 2009 SME gazelles are accountable for a higher vacancy share in relation to the average of all the Slovenian small and medium firms. In consistence with the research results of numerous other authors (e.g. Birch, 1987; Bosma \& Levie, 2010; Roure, 1999; Schreyer, 2000), small firms are the biggest job generators - in our example all the micro, small and medium fast-growing firms (SMEs). The reasons for the bigger average number of employees in the Slovenian large companies should be linked to their long tradition. In the majority of cases, these are business systems that very slowly adapt to structural changes and do not depend so much on the market conditions, as it is the case with the large companies in the gazelles group. The further analysis has shown that the size of a Slovenian fast-growing company has an impact on its higher employment growth rate. The micro-gazelles and small gazelles show lower growth rates, whereas the medium gazelles and especially the large gazelles display the markedly higher rates of super-fast and hyper-fast employment growth than expected. We have substantiated the obtained results using an assertion made by R. D. Ireland at al (2001, in: Steffens et al, 2009, 126), who claim that the bigger the company is, the more funds and more opportunities it has to further develop its competitive advantages and to successfully implement a fast growth strategy. Also, M. E. Porter (1985) says that scale economies are more convenient. We can also say that the average labor productivity (measured as the value added per employee) in the Slovenian gazelles is 2.3 times as high as the average productivity of all Slovenian companies. We can partly substantiate our claims by citing J. Bos and E. Stam (2011, 11), who say "that gazelles are relatively capital-intensive enterprises and thus employ less persons for achieving the equal amount of value added"; in other words, their value added per employee is all that much higher. We therefore conclude that innovative and fast-growing companies are a great potential for creating value added and they make a valuable contribution to growth and the development of the economy.

Of course, some limitations of the study should be pointed out. The first is that it only examines a limited national sample of the 500 fastest-growing companies in Slovenia. The second important limitation is the selected indicator for measuring company growth (the DaBeg index). The third limitation is the topic itself of the study of fast-growing companies, which only refers to the two growth indicators - employment and value added per employee. The final limitation worth mentioning is the comparative criterion of the proposed research - the population of the Slovenian SMEs. 
A better understanding of the described phenomenon is very important for various target groups. From the theoretical point of view, knowledge of this kind of gazelles can corroborate the empirical micro-level of entrepreneurship theories. From the social point of view, more knowledge of the factors stimulating or hindering fast company growth can also be useful for owners, consumers and, ultimately, the whole community. When proposals for policy makers are concerned, it is important to emphasize that support measures must not only be directed to entrepreneurship in general, but also towards those individuals and enterprises that are motivated for growth, i.e. towards those who have big aspirations in that respect. To activate the entrepreneurial potential of these individuals, it is important that technological and growth-oriented entrepreneurship be promoted. Establishing the right incentives and promoting the role models are crucial. Growth is significantly based on the mindset of the entrepreneur. A decision to grow must first be accepted, only to be followed by the whole array of activities to be undertaken. Policymakers should also consider that mindsets are different and that many different cultural, economic, and social factors influence their formation. Entrepreneurs are different, and further research is needed to distinguish policy instruments for boosting growth-oriented entrepreneurship. According to many researches, they express different aspirations and need to be treated separately; to support high-growth ventures, the personal characteristics of the leading entrepreneur should also be considered.

We think that this kind of research contributes to finding out more efficient instruments for government policy makers, which are meant to stimulate and promote growth-oriented entrepreneurship. The understanding of dynamic entrepreneurship is namely one of the important bases for planning an entrepreneurship policy in the field of stimulating company growth in the European Union and beyond.

The conclusions of this paper lead us to establish a series of proposals for future studies. A possible line of research would be its extension to a comparison between the selected countries (for example the Eastern European countries). In order to verify the reliability of the selected measures of growth (DaBeg), additional objective measures of growth or sets of integrated growth measures (sales, employment and assets growth) would be recommendable. The development of a longitudinal study would allow us to use multiple clocks to evaluate the influence of several variables on fast growth entrepreneurs' patterns. The focus of our research was on the fast-growing Slovenian companies. It would be interesting to make a comparison between different groups of entrepreneurs (for example serial entrepreneurs or different age groups of entrepreneurs etc.). Finally, we consider it to be of great importance to study in depth, from a configurational approach, the relationship between companies' growth and their long term success.

\section{ENDNOTES}

1 Starting index year 1998 (for gazelles in 2003) and 2004 (for gazelles in 2009).

2 Final index year 2002 (for gazelles in 2003) and 2008 (for gazelles in 2009).

3 Growth index 2002-1998 (for gazelles in 2003) and growth index 2008-2004 (for gazelles in 2009).

4 Gazelles in the „large company” group (large gazelles) account for a total of $4 \%$ of the population, and therefore are excluded from this comparison (they do not meet the criteria of the hypothesis, because none of the expected frequencies surpass 1 ). However, it is necessary to note that all the large gazelles achieved the so-called ,hyper fast growth"

\section{REFERENCES}

Autio, E,. \& Acs, Z. (2009). Institutional Influence on Strategic Entrepreneurial Behaviours. Jena Economic Research Papers in Economics. Jena: Max Planck Institute, 2009-080.

Basle, A. (2003). E-misija je zamenjala Comito. Gospodarski vestnik.

Baum, R., Locke, E., \& Smith, K. (2001). Multidimensional Model of Venture Growth. The Academy of Management Journal, 44(2), 292-303. http://dx.doi.org/10.2307/3069456

Birch, D. L. (1979). The Job Generation Process. Massachusetts Institute of Technology, Program on Neighborhood and Regional Change. Massachusetts: Cambridge. 
Birch, D. L. (1981). Who Creates Jobs? The Public Interest, 65(Fall), 3-14.

Birch, D. L. (1987). Job Creation in America. New York: Free Press.

Bos, J., \& Stam, E. (2011). Gazelles, Industry Growth and Structural Change. Discussion Paper Series nr: 11-02, Tjalling C. Koopmans Research Institute, Utrecht, The Netherlands: Utrecht School of Economics.

Bosma, N., \& Levie, J. (2010). Global Entrepreneurship Monitor, 2009 Executive Report. Babson College, Babson Park, MS, US; Universidad del Desarrollo, Santiago, Chile; Haskolinn Reykjavik, Iceland, Reykjavik University; London Business School, London, UK and GERA.

Boštjančič, M. (2005). Primerjava slovenskih gazel z evropskimi in ameriškimi. Unpublished master thesis, Fakulteta za management, Koper, Slovenia.

Cassar, G. (2007). Money, Money, Money? A Longitudinal Investigation of Entrepreneur Career Reason, Growth Preferences and Achieved Growth. Entrepreneurship \& Regional Development, 19(1), 89-107. http://dx.doi. org/10.1080/08985620601002246

Delmar, F., Davidsson, P., \& Gartner, W. B. (2003). Arriving at the High-growth Firm. Journal of Business Venturing, 18(2), 189-216. http://dx.doi.org/10.1016/S0883-9026(02)00080-0

Dunne, P., \& Hughes, A. (1996). Age, Size, Growth and Survival: UK Companies in the 1980s. J. Ind. Econ, XLII (2), 115-140.

Europe's 500 (2011a). The European Growth Companies, Europe's 500 List - Birch Index. Retrived January 10, 2011, from http:// www.europes500.eu/birch-index.html

Europe's 500 (2011b). The European Growth Companies, Europe's 500 List - History 2007. Retrived January 10, 2011, from http:// www.europes500.eu/results-history2007.html

European Commission (2010). European SMEs under Pressure, Annual Report on EU Small and Medium-sized Enterprises 2009. Retrived December 12, 2010, from http://ec.europa.eu/ enterprise/policies/sme/facts-figures-analysis/performancereview/index_en.htm

Evans, D. S. (1987). Test of Alternative Theories of Firm Growth. Journal of Political Economy, 95, 657-674.

Gibrat, R. (1931). Les Inégalités économiques. Paris: Siley. http:// dx.doi.org/10.1086/261480

Gilbert, B. A., McDougall, P. P., \& Audretsch, D. B. (2006). New Venture Growth: A Review and Extension Global. Journal of Management, 32(6), 926-950. http://dx.doi. org/10.1177/0149206306293860
Henrekson, M., \& Johansson, D. (2010). Gazelles as Job Creators: A Survey and Interpretation of the Evidence. Small Business Economics, 35, 227-244. http://dx.doi.org/10.1007/ s11187-009-9172-z

Ireland, R. D., Hi, M. A., \& Simon, D. G. (2003). A Model of Strategic Entrepreneurship: The Construct and its Dimensions. Journal of Management, 29(6), 963-989. http:// dx.doi.org/10.1016/S0149-2063_03_00086-2

Landström, H. (2005). Pioneers in Entrepreneurship and Small Business Research. Springer. http://dx.doi.org/10.1007/b102095

Markman, G. D., \& Gartner, W. B. (2002). Is Extraordinary Growth Profitable? A Study of inc. 500 High-growth Companies, Entrepreneurship. Theory and Practice, 27(1), 65-75. http://dx.doi.org/10.1111/1540-8520.t01-2-00004

Močnik, D. (2010). Temeljne značilnosti slovenskega podjetništva $\mathrm{v}$ primerjavi z evropskim. In: K. Širec \& M. Rebernik (Eds.), Vrzeli slovenskega podjetniškega okolja: Slovenski podjetniški observatorij 2009/2010 (17-44). Maribor: Ekonomsko-poslovna fakulteta, UM.

Morris, R. (2011). 2011 High-Impact Entrepreneurship Global Report. Ernst \& Young, Center for High-Impact Entrepreneurship at Endeavor. Retrived September 5, 2012, from http://www. gemconsortium.org/docs/download/295

Niskanen, M., \& Niskanen, J. (2007). The Determinants of Firm Growth in Small and Micro Firms - Evidence on Relationship Lending Effects. Retrived June 22, 2012, from http://ssrn.com/ abstract=874927. http://dx.doi.org/10.2139/ssrn.874927

Penrose, E. T. (1959). The Theory of the Growth of the Firm, $3^{\text {rd }}$ ed. Oxford: Oxford University Press.

Phillips, B., \& Kirchhoff, B. (1989). Formation, Growth and Survival: Small Firm Dynamics in the US Economy. Small Business Economics, 1(1), 65-74. http://dx.doi.org/10.1007/ BF00389917

Porter, M. E. (1985). Competitive Advantage. New York: Free Press.

Pšeničny, V. (2008). 5000 malih je ustvarilo velik del rasti. Poslovni dnevnik. Retrived June 22, 2012, from http://www.dnevnik. si/tiskane_izdaje/dnevnik/1042222623

Rebernik, M., Tominc, P., Crnogaj, K., Širec, K., \& Bradač Hojnik, B. (2013). Nezaznane priložnosti: GEM Slovenija 2012, Maribor: Ekonomsko-poslovna fakulteta, UM.

Rebernik, M., Širec, K., \& Močnik, D. (2014). Stanje slovenskega podjetništva in izzivi izobraževanja za podjetnost. Maribor: Ekonomsko-poslovna fakulteta, UM. 
Roper, S. (1999). Modelling Small Business Growth and Profitability. Small Business Economics, 13, 235-252. http:/ dx.doi.org/10.1023/A:1008104624560

Roure, J. (1999). 500 najhitreje rastočih evropskih podjetij. Podjetnik, nov, 52-53.

Schreyer, P. (2000). High-Growth Firms and Employment. OECD Science, Technology and Industry Working Papers, 2000/3, Paris: OECD Publishing. http://dx.doi. org/10.1787/861275538813

Sexton, D. L., \& Smilor, R. W. (1997). Entrepreneurship 2000. Chicago: Upstart Publishing Company.

Solina, A. (2011). Analiza zaposlovanja in nekaterih kazalnikov uspešnosti slovenskih gazel. Unpublished master thesis, Ekonomsko-poslovna fakulteta, UM, Maribor, Slovenia.

Steffens, P., Davidsson, P., \& Fitzsimmons, J. (2009). Performance Configurations Over Time: Implications for Growth- and Profit-oriented Strategies. Entrepreneurship Theory and Practice, 33(1), 125-148. http://dx.doi.org/10.1111/ j.1540-6520.2008.00283.x
Storey, D. J. (1995). Symposium on Harrison's "Lean and Mean": A Job Generation Perspective. Small Business Economics, 7(5), 5-8. http://dx.doi.org/10.1007/BF01302731

Sutton, J. (1997). Gibrat's legacy. J. Econ. Lit. 35, 40-59.

Wagner, J. (1992). Firm Size, Firm Growth, and Persistence of Change: Testing Gibrat's Law with Establishment Data Firm Lower Saxony, 1978-1989. Small Business Economics, 4(2), 125-131. http://dx.doi.org/10.1007/BF00389853

Wicklund, J., \& Shepherd, D. (2003). Aspiring for, and Achieving Growth: The Moderating Role of Resources and Opportunities. Journal of Management Studies, 40(8), 19191941. http://dx.doi.org/10.1046/j.1467-6486.2003.00406.x

Zhou, H., \& de Witt, G. (2009). Determinants and Dimensions of Firm Growth, (February 12). SCALES EIM Research Reports (H200903). Retrived August 20, 2012, from http://ssrn.com/ abstract=1443897, or http://dx.doi.org/10.2139/ssrn.1443897]. http://dx.doi.org/10.2139/ssrn.1443897

Received on $17^{\text {th }}$ December 2013, after revision, accepted for publication on $17^{\text {th }}$ April 2014.

Katja Crnogaj, PhD, is a research and teaching assistant of Entrepreneurship and Business Economics in the Department for Entrepreneurship and Business Economics at the Faculty of Economics and Business, University of Maribor, Slovenia. Her research interest includes entrepreneurship, international entrepreneurship, entrepreneurial measures, entrepreneurship policy, networking and some other areas of entrepreneurship and business economics.

Karin Širec, $\mathrm{PhD}$, is an associate professor of Entrepreneurship and Business Economics in the Department for Entrepreneurship and Business Economics at the Faculty of Economics and Business, University of Maribor, Slovenia. Her research interest includes general entrepreneurship, business growth, women entrepreneurship and entrepreneurship policy. 


\title{
DOPRINOS SLOVENAČKIH BRZO-RASTUĆIH PREDUZEĆA (GAZELA) ZAPOSLENOSTI I DODATOJ VREDNOSTI
}

\author{
Katja Crnogaj, Karin Širec \\ Fakultet za ekonomiju i biznis Univerziteta u Mariboru, Maribor, Slovenija
}

\begin{abstract}
Preduzeća sa visokom stopom rasta, tzv. gazele, odgovorna su za podsticanje ekonomskog rasta i razvoja preko stopa ekstremnog rasta (zaposlenost, prihodi, sredstva, dodata vrednost itd.). Shodno tome, istraživanje brzo-rastućih preduzeća može pružiti dragocene uvide u promovisanje dinamičnog preduzetništva u savremenom društvu. U ovom radu, ispitujemo preduzeća koja se odlikuju brzim rastom i njihov društveno-ekonomski doprinos na osnovu veličine preduzeća, zato što je dimenzija veličine jednog preduzeća bitna karakteristika koja utiče na nivo zaposlenosti i značajno doprinosi rastu zaposlenosti. Na osnovu nacionalnog rangiranja 500 preduzeća sa tendencijom najbržeg rasta, na osnovu podataka iz bilansa uspeha (rast prodaje u datom petogodišnjem periodu), poredimo gazele sa prosekom svih slovenačkih preduzeća. Rezultati istraživanja ukazuju na to da gazele znatno doprinose zaposlenosti i stvaranju dodate (novostvorene) vrednosti. Rast preduzeća može se, takođe, meriti na osnovu drugih parametara, i stoga, $u$ jednom delu analize koju smo sproveli, korišćenje mera ograničavamo na relativni rast zaposlenosti - DaBeg indeks. Rezultati pokazuju da su obrasci rasta među preduzećima heterogeni, a da inovativna preduzeća sa tendencijom najbržeg rasta daju dragocen društveno-ekonomski doprinos. Kao takve, gazele zahtevaju postojanje efektivnih mera podrške vladinih politika, koje imaju za cilj podsticanje i promovisanje preduzetništva usmerenog na rast.
\end{abstract}

Ključne reči: preduzeća sa visokim rastom (gazele), DaBeg indeks, mala i srednja preduzeća, rast zaposlenosti, dodata vrednost

JEL Classification: L25, L26 